\title{
THE STUDY OF SURFACE WATER QUALITY IN BUYUK MENDERES RIVER (TURKEY): DETERMINATION OF ANIONIC DETERGENT, PHOSPHATE, BORON AND SOME HEAVY METAL CONTENTS
}

\author{
MINARECI, O. ${ }^{*}-$ CAKIR, M. $^{2}-$ MINARECI, E. ${ }^{1}$ \\ ${ }^{1}$ Department of Biology, Faculty of Sciences and Arts, Manisa Celal Bayar University \\ 45140 Manisa, Turkey \\ (phone: +90-236-201-3278; fax: +90-236-201-3040) \\ ${ }^{2}$ Graduate School of Natural and Applied Sciences, Manisa Celal Bayar University \\ 45140 Manisa, Turkey \\ (e mail: cakirrmurat@hotmail.com) \\ *Corresponding author \\ e-mail: orkide.minareci@cbu.edu.tr;+90-236-201-3278; fax:+90-236-201-3040
}

(Received $14^{\text {th }}$ Jun 2018; accepted $1^{\text {st }}$ Aug 2018)

\begin{abstract}
The Buyuk Menderes basin is very wide and the people living here deal with farming, which increases the importance of the river to the region. The pollution of the river increases because the industry, urbanization and agricultural activities are very intense in the river basin. For this reason, the aim of this study is to map the extent of pollution of Buyuk Menderes River, to detect sources causing pollution in the river and also to suggest solutions for taking necessary precautions. Anionic detergent, phosphate, boron and heavy metal concentrations were determined in water samples taken from Buyuk Menderes River in this study. Mean concentrations of anionic detergent, phosphate, boron, copper, chrome, nickel and lead were found $0.2345 \mathrm{mg} \mathrm{l}^{-1}, 0.0181 \mathrm{mg} \mathrm{l}^{-1}, 0.8352 \mathrm{mg} \mathrm{l}^{-1}, 0.0035 \mathrm{mg} \mathrm{l}^{-1}$, $0.0045 \mathrm{mg} \mathrm{l}^{-1}, 0.0247 \mathrm{mg} \mathrm{l}^{-1}, 0.0002 \mathrm{mg} \mathrm{l}^{-1}$, respectively.
\end{abstract}

Keywords: surfactant, freshwater, nickel, pollution, water quality classes

\section{Introduction}

Rapid population growth, the spreading of industrialization and mechanization of agriculture, cause pollution of the environment and the waters. Pollution is caused by the inability of people to perceive the importance of environmental conditions for life. Due to uncontrolled domestic and industrial wastes and agricultural activities, it is known that pollution reaches important dimensions in many water resources today (Akın and Akın, 2007). Büyük Menderes River is one of Turkey's important and large river. The River has been polluted by factors such as domestic wastewater, industrial wastewater, excessive, untimely and incorrect use of fertilizer and pesticide. These incidents require investigating pollution levels of the river. For this reason, the aim of this study is to map the extent of pollution of Buyuk Menderes River, to detect sources causing pollution in the river and also to suggest solutions for taking necessary precautions.

There are also detergents among pollutants coming from domestic and industrial wastes to aquatic environments. Detergents are used in general cleaning work. The detergents contain anionic surfactants such as alkyl sulphate or alkyl aryl sulphonate as the main cleaner and other materials that help the cleaning process. Detergents are mixtures of powder, granule, soft consistency or liquid. The detergents cause problems 
like disturbing the taste of drinking water, making foam, preventing the water cleaning process, damaging the aquatic organisms by reducing the amount of dissolved oxygen, shortening the aging process of lakes by eutrophication due to phosphate content and damaging the aquatic life (Egemen, 2011).

Approximately half of phosphorus comes from the phosphate in the composition of detergents used in domestic wastewater. $91 \%$ of the phosphorus comes from domestic and industrial wastes and 9\% from agricultural areas to water resources (Egemen, 2011).

Boron compounds are commonly found in surface and ground waters. The toxic limit value of the boron element is $1.0 \mathrm{mg} \mathrm{l}^{-1}$. This value is determined for plants, animals and humans. Also this value is an acceptable for drinking and irrigation waters and wastewater (Kabay et al., 2006).

Elements like selenium, iron, manganese and cobalt are mixed from the soil to the water. Magnesium, potassium and cobalt are passed from the sea to the air. Toxic elements such as zinc, copper, cadmium, mercury, antimony, arsenic, argon, lead, chromium, selenium mix to the air, water and soil by anthropogenic activities (Samsunlu, 1999).

\section{Materials and methods}

The cities of Aydin and Denizli are located in the Aegean region. These cities are important industrial and agricultural centers of Turkey.

The Buyuk Menderes River comes from Afyon, passes through Usak, Denizli and Aydin, reaches to the Aegean Sea. The total length of the Buyuk Menderes is about $584 \mathrm{~km}$ and its basin covers $25000 \mathrm{~km}^{2}$ (Boyacioglu et al., 2004).

In this research, six stations were determined in the discharge regions in Buyuk Menderes River (Fig. 1). The coordinates of the stations were showed in the Table 1.

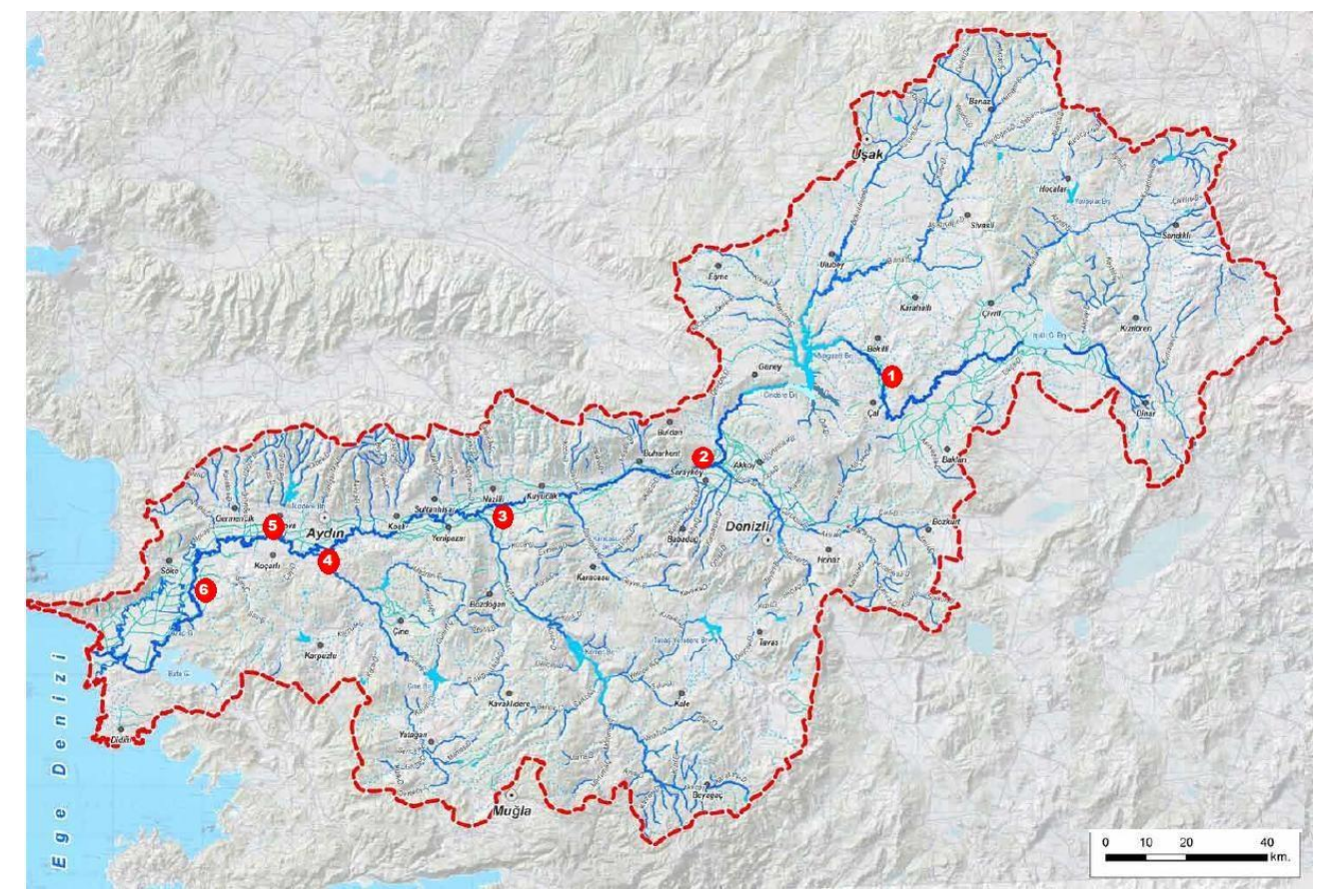

Figure 1. Sampling points 
Table 1. Coordinates of stations

\begin{tabular}{c|c|c}
\hline & Stations & Coordinates \\
\hline 1 & Kumralli & $38^{\circ} 6^{\prime} 1.62^{\prime \prime} \mathrm{N}, 29^{\circ} 25^{\prime} 22.26^{\prime \prime} \mathrm{E}$ \\
2 & Saraykoy & $37^{\circ} 57^{\prime} 5.73^{\prime \prime} \mathrm{N}, 28^{\circ} 54^{\prime} 58.00^{\prime \prime} \mathrm{E}$ \\
3 & Nazilli & $37^{\circ} 52^{\prime} 33.28^{\prime \prime} \mathrm{N}, 28^{\circ} 19^{\prime} 39.26^{\prime \prime} \mathrm{E}$ \\
4 & Aydın & $37^{\circ} 46^{\prime} 56.76^{\prime \prime} \mathrm{N}, 27^{\circ} 50^{\prime} 22.99^{\prime \prime} \mathrm{E}$ \\
5 & Kocarl & $37^{\circ} 48^{\prime} 36.57^{\prime \prime} \mathrm{N}, 27^{\circ} 42^{\prime} 47.00^{\prime \prime} \mathrm{E}$ \\
6 & Soke & $37^{\circ} 42^{\prime} 26.93^{\prime \prime} \mathrm{N}, 27^{\circ} 28^{\prime} 36.62^{\prime \prime} \mathrm{E}$ \\
\hline
\end{tabular}

As a research material, water samples taken from six stations were selected. The water samples were taken on a monthly basis. They were collected between July 2012June 2013. $\mathrm{pH}$, temperature, dissolved oxygen, total dissolved substance and conductivity parameters were measured by TOA WQC (Water Quality Checker) - 20A.

The method in the determination of anionic detergent is based on the spectrophotometric measurement of methylene blue by being dissolved in the chloroform of the blue colored salt resulting from the anionic surfactant reaction (Anonymous, 1995). Orthophosphate phosphorus is determined by measuring the bluecolored phosphomolybdic acid in the spectrophotometer resulting from the reaction with ascorbic acid, ammonium molybdate and potassium antimony tartrate in acidic environment (Parsons et al., 1984). Determination of the amount of boron is based on the spectrophotometer measurement of the color compound formed with the carmin, a specific reagent of the tube (Hatcher and Wilcox, 1950; Anonymous, 2005). Heavy metal analysis of prepared water samples were made in ICP-MS (Inductively Coupled Plasma - Mass Spectrophotometer).

Statistical analyzes were performed using Windows, Graphpad Prism software package. "One-way Anova" variance analysis was applied to detect whether the amounts of anionic detergent, phosphorus, boron and heavy metals showed significant difference among months and stations. "Tukey test" was applied to detect in which stations and months the significant differences.

\section{Result and discussion}

In this study, anionic detergent, phosphate, boron and heavy metal concentrations were detected in the water samples from Buyuk Menderes River that flows from Denizli and Aydin cities centers. $\mathrm{pH}$, temperature, dissolved oxygen, total soluble substance and conductivity parameters were measured. On average, $\mathrm{pH} 8.24$, temperature $15.6{ }^{\circ} \mathrm{C}$, dissolved oxygen $6.04 \mathrm{mg} \mathrm{l}^{-1}$, total soluble substance $426 \mathrm{mg} \mathrm{l}^{-1}$ and conductivity $470 \mu \mathrm{S} / \mathrm{cm}$ were found. The river water in terms of $\mathrm{pH}$ and dissolved oxygen parameters 2nd quality and in terms of all other parameters 1st quality in water class were found, according to the Water Pollution Control Regulation (Official Gazette, 2004) (Table 2).

These mean values were compared with the Aboveground Water Quality Regulation "Quality Criteria According to Classes in Terms of General Chemical and Physicochemical Parameters of Coastal Waters" (Official Gazette, 2012). The river water was determined as the $2^{\text {nd }}$ quality in terms of $\mathrm{pH}$ and conductivity parameters and the 3rd quality in terms of dissolved oxygen parameter (Table 3). 
Table 2. Quality criteria (Official Gazette, 2004)

\begin{tabular}{|c|c|c|c|c|c|}
\hline \multirow{2}{*}{ Water quality parameters } & \multicolumn{4}{|c|}{ Water quality classes } & \multirow{2}{*}{ This study } \\
\hline & $1^{\text {st }}$ & $2^{\text {nd }}$ & $3^{\text {rd }}$ & $4^{\text {th }}$ & \\
\hline Temperature $\left({ }^{\circ} \mathrm{C}\right)$ & 25 & 25 & 30 & $>30$ & 15.6 \\
\hline $\mathrm{pH}$ & $6.5-8.5$ & $6.5-8.5$ & $6.0-9.0$ & 6.0-9.0 except & 8.24 \\
\hline Dissolved oxygen $\left(\mathrm{mg} \mathrm{l}^{-1}\right)$ & 8 & 6 & 3 & $<3$ & 6.04 \\
\hline Total soluble substance $\left(\mathrm{mg}^{-1}\right)$ & 500 & 1500 & 5000 & $>5000$ & 426 \\
\hline Surfactant $\left(\mathrm{mg} \mathrm{l}^{-1}\right)$ & 0.05 & 0.2 & 1 & $>1.5$ & 0.2345 \\
\hline Boron $\left(\mathrm{mg} \mathrm{l}^{-1}\right)$ & 1 & 1 & 1 & $>1$ & 0.8352 \\
\hline Total phosphorus $\left(\mathrm{mg} \mathrm{l}^{-1}\right.$ ) & 0.02 & 0.16 & 0.65 & $>0.65$ & 0.0181 \\
\hline Copper $\left(\mu \mathrm{g}^{-1}\right)$ & 20 & 50 & 200 & $>200$ & 3.5 \\
\hline Chrome $\left(\mu \mathrm{g}^{-1}\right)$ & 20 & 50 & 200 & $>200$ & 4.5 \\
\hline Nickel $\left(\mu \mathrm{g} 1^{-1}\right)$ & 20 & 50 & 200 & $>200$ & 24.7 \\
\hline Lead $\left(\mu \mathrm{g}^{-1}\right)$ & 10 & 20 & 50 & $>50$ & 0.2 \\
\hline
\end{tabular}

Table 3. Quality criteria (Official Gazette, 2012)

\begin{tabular}{c|c|c|c|c|c}
\hline \multirow{2}{*}{ Water quality parameters } & \multicolumn{4}{|c}{ Water quality classes } & \multirow{2}{*}{ This study } \\
\cline { 2 - 5 } & $\mathbf{1}^{\text {st }}$ & $\mathbf{2}^{\text {nd }}$ & $\mathbf{3}^{\text {rd }}$ & $\mathbf{4}^{\text {th }}$ & \\
\hline $\mathrm{pH}$ & $6-9$ & $6-9$ & $6-9$ & $6-9$ & $\mathbf{8 . 2 4}$ \\
Conductivity $(\mu \mathrm{s})$ & $<400$ & 1000 & 3000 & $>3000$ & $\mathbf{4 7 0}$ \\
Dissolved oxygen $\left(\mathrm{mg} \mathrm{l}^{-1}\right)$ & $>8$ & 6 & 3 & $<3$ & $\mathbf{4 . 9 4}$ \\
\hline
\end{tabular}

Mean concentrations of anionic detergent, phosphate, boron, copper, chrome, nickel and lead were found $0.2345 \mathrm{mg} \mathrm{l}^{-1}, 0.0181 \mathrm{mg} \mathrm{l}^{-1}, 0.8352 \mathrm{mg} \mathrm{l}^{-1}, 0.0035 \mathrm{mg} \mathrm{l}^{-1}, 0.0045$ $\mathrm{mg} \mathrm{l}^{-1}, 0.0247 \mathrm{mg} \mathrm{l}^{-1}, 0.0002 \mathrm{mg} \mathrm{l}^{-1}$, respectively. Anionic detergent, phosphate, boron and heavy metal concentrations mean values were presented in Table 4. These concentrations were compared with the Water Pollution Control Regulation (Official Gazette, 2004). Buyuk Menderes River is in the class of less polluted water ( $2^{\text {nd }}$ class) in terms of anionic surfactant and nickel (Table 2). Because the Buyuk Menderes River is close to the settlements, it is thought that the discharges are reaching to the river. Due to domestic waste load, the anionic detergent load increases. The average anionic detergent concentration $\left(0.2345 \mathrm{mg} \mathrm{l}^{-1}\right)$ is below the surfactant concentration, which is considered to be $\leq 0.3 \mathrm{mg} \mathrm{l}^{-1}$ in European Union quality criteria. The average heavy metal values were compared with the heavy metal concentrations allowed in the irrigation waters specified in the Water Pollution Control Regulation Technical Procedures Bulletin (Official Gazette, 1991) and the metal concentrations were found to be low.

According to the One Way ANOVA test, statistically significant differences were not found for heavy metals, $\mathrm{pH}$, dissolved oxygen, total soluble substance and conductivity $(p>0.05)$ and differences were found for phosphate $(p<0.05)$. Also the difference among the stations was statistically insignificant $(\mathrm{p}>0.05)$ and the difference among the months was statistically significant $(\mathrm{p}<0.05)$ for anionic detergent and boron amounts (Table 5). 


$$
-5291-
$$

Table 4. Monthly average concentrations of detergent, phosphate, boron, copper, chromium, nickel and lead in water samples of Buyuk Menderes River (mg $\left.l^{-1}, \pm S D<0.001\right)$

\begin{tabular}{c|c|c|c|c|c|c|c}
\hline Months & Detergent & Phosphate & Boron & Copper & Chrome & Nickel & Lead \\
\hline July & 0.1812 & 0.0117 & 0.6397 & 0.0203 & 0.0010 & 0.0277 & 0.0000 \\
August & 0.1615 & 0.0102 & 0.6733 & 0.0032 & 0.0014 & 0.0317 & 0.0003 \\
September & 0.0583 & 0.0087 & 0.3215 & 0.0012 & 0.0017 & 0.0283 & 0.0004 \\
October & 0.2297 & 0.0228 & 0.8938 & 0.0018 & 0.0009 & 0.0320 & 0.0004 \\
November & 0.3345 & 0.0207 & 1.0681 & 0.0025 & 0.0010 & 0.0557 & 0.0002 \\
December & 0.3260 & 0.0173 & 0.3407 & 0.0037 & 0.0004 & 0.0637 & 0.0001 \\
January & 0.1442 & 0.0182 & 0.7017 & 0.0012 & 0.0008 & 0.0310 & 0.0000 \\
February & 0.3385 & 0.0237 & 0.6259 & 0.0032 & 0.0015 & 0.0051 & 0.0001 \\
March & 0.2227 & 0.0153 & 0.8025 & 0.0018 & 0.0094 & 0.0081 & 0.0002 \\
April & 0.2442 & 0.0245 & 1.1856 & 0.0008 & 0.0169 & 0.0070 & 0.0002 \\
May & 0.3200 & 0.0228 & 1.3985 & 0.0010 & 0.0123 & 0.0036 & 0.0002 \\
June & 0.2528 & 0.0208 & 1.3715 & 0.0019 & 0.0070 & 0.0034 & 0.0002 \\
MEAN & $\mathbf{0 . 2 3 4 5}$ & $\mathbf{0 . 0 1 8 1}$ & $\mathbf{0 . 8 3 5 2}$ & $\mathbf{0 . 0 0 3 5}$ & $\mathbf{0 . 0 0 4 5}$ & $\mathbf{0 . 0 2 4 7}$ & $\mathbf{0 . 0 0 0 2}$ \\
\hline
\end{tabular}

Each value is the average of 3 samples from 6 stations with three repetitions $(n=54)$

Table 5. The result of the one-way ANOVA test between months and stations

\begin{tabular}{c|c|c|c|c|c|c}
\hline Table analyzed & \multicolumn{3}{|c|}{ Between months } & \multicolumn{3}{c}{ Between stations } \\
\hline $\begin{array}{c}\text { One-way analysis of } \\
\text { variance }\end{array}$ & Detergent & Phosphate & Boron & Detergent & Phosphate & Boron \\
\hline P value & $\begin{array}{c}\text { P<0.0001 } \\
* * *\end{array}$ & $\mathbf{0 . 0 0 0 2}$ & P $<\mathbf{0 . 0 0 0 1}$ & & $\mathbf{0 . 0 0 6 7}$ & \\
P value summary & *** & $* * *$ & & $* *$ & \\
Are means signif. different? & Yes & Yes & Yes & No & Yes & No \\
(p < 0.05) & 12 & 12 & 12 & & 6 & \\
Number of groups & 8.752 & 4.071 & 4.233 & & 3.549 & \\
F & 0.6161 & 0.4274 & 0.437 & & 0.2119 & \\
R squared & & & & & &
\end{tabular}

The differences among the months and stations were determined by the Tukey test. Tukey test results are shown in Tables 6, 7 and 8. Especially in summer, the decline in detergent quantities can be attributed to the decline in population at residential areas as well as the decline in domestic waste loads in these months (Table 6). 50\% of the amount of phosphorus in domestic wastewater is caused by the detergent-based phosphates used in houses. As a result, the amount of phosphate has decreased in parallel with the decrease in the amount of detergent (Table 7). Increase in detergent values in winter months, can be considered as an increase of domestic waste load transport to river with the increase of rainfall. Significant boron differences were showed in May and June (Table 8). Boron concentrations were high in May and June. Especially in May and June, together with agricultural irrigation using groundwater resources, abundant amounts of boron in underground waters are mixed in to Buyuk Menderes River. 
Table 6. The result of the Tukey test among the months (anionic detergent) (only significant values)

\begin{tabular}{c|c|c|c|c|c|c|c}
\hline & Jul & Aug & Sep & Oct & Nov & Dec & Jan \\
\hline Jun & & & 0.0011 & & & & \\
May & & 0.017 & $<0.0001$ & & & & 0.0047 \\
Apr & & & 0.0022 & & & & \\
Mar & & & 0.0112 & & & & \\
Feb & 0.0185 & 0.0043 & $<0.0001$ & & & & 0.0011 \\
Jan & & & & & 0.0015 & 0.003 & \\
Dec & 0.0428 & 0.0111 & $<0.0001$ & & & & \\
Nov & 0.0244 & 0.0059 & $<0.0001$ & & & & \\
Oct & & & 0.0067 & & & & \\
\hline
\end{tabular}

Table 7. The result of the Tukey test between months and stations (phosphate) (only significant values)

\begin{tabular}{l|c|c|c|c}
\hline & Aug & Sep & \multicolumn{2}{|c}{ St 1 } \\
\hline May & & 0.0232 & St 6 & 0.0182 \\
Apr & 0.0205 & 0.0063 & St 5 & 0.0445 \\
Feb & 0.0378 & 0.0123 & St 3 & 0.0058 \\
Oct & & 0.0232 & & \\
\hline
\end{tabular}

Table 8. The result of the Tukey test among the months (boron) (only significant values)

\begin{tabular}{c|c|c}
\hline & Sep & Dec \\
\hline Jun & 0.004 & 0.0051 \\
May & 0.0028 & 0.0036 \\
Apr & 0.0384 & 0.0474 \\
\hline
\end{tabular}

When we compared the values with the results of other studies which investigated anionic detergent, phosphate, boron and heavy metal levels of Buyuk Menderes, we measured similar values in present study. In the study in Buyuk Menderes River, average copper $0.011 \mathrm{ppm}$, chromium $0.012 \mathrm{ppm}$, nickel $0.01 \mathrm{ppm}$, lead $0.011 \mathrm{ppm}$, iron $0.006 \mathrm{ppm}$, mangan $0.09 \mathrm{ppm}$, zinc $0.051 \mathrm{ppm}$, cobalt $0.08 \mathrm{ppm}$ were found (Akcay et al., 2003). The average boron value of the Buyuk Menderes River was determined as $0.6 \mathrm{mg} \mathrm{l}^{-1}$ in another study. According to all parameters, it was stated that the water was mostly polluted in Saraykoy and Nazilli regions (Kucuk, 2007). Boron content was found to be between 0.33 and $6.41 \mathrm{mg} \mathrm{l}^{-1}$. The boron concentration is high especially in the regions of under ground thermal water resources (Aydin and Seferoglu, 2000). And the boron concentration was found to be $1.1 \mathrm{mg} \mathrm{l}^{-1}$ due to geothermal wastewater discharges to the river and river water used for agricultural irrigation affected the production of agricultural products (Akar, 2007). Buyuk Menderes River is 
in the third class pollution level due to domestic and industrial wastes and agricultural activities (Akın and Akın, 2007).

"Pollution of the Buyuk Menderes is to pollute the future" in the project final report, the mean values were compared with the Water Pollution Control Regulation. Buyuk Menderes River is $2^{\text {nd }}$ class, namely in the class of less polluted water in terms of lead and $1^{\text {st }}$ class, namely it is high quality water in terms of copper, chrome and zinc. It is below the permissible limits when compared with the maximum allowable concentrations of heavy metals and toxic elements in irrigation waters (Durdu et al., 2012).

It is stated that the most serious problems in terms of water quality in rivers in Buyuk Menderes basin are excessive organic matter, nitrogen, $\mathrm{pH}$, boron and heavy metal pollution (Tubitak Mam, 2013).

Isıklı Lake is on resources that feed the Buyuk Menderes River. Isıkl Stream is a branch of the Buyuk Menderes River. Isıklı Lake and Isıklı Stream were determined to be as $2^{\text {nd }}$ class (less contaminated water) in terms of anionic detergent parameter (Cakir and Minareci, 2015). Also in Isıkl Lake, it was found that organic pollution significantly increased and the amount of dissolved oxygen decreased in summer in some stations of the lake. It is stated that the important source that pollutes the lake is Buyuk Menderes River (Bulut et al., 2012). Adiguzel Dam Lake is on the Buyuk Menderes River. Adiguzel Dam Lake was categorized as less contaminated water in terms of anionic detergent parameter (Minareci and Cakir, 2018).

The measured values in the different rivers in the same region are higher than the measured values in our study. The Gediz River is highly polluted surface water in the Gediz Basin. Due to domestic and industrial wastes and agricultural activities, the river is determined as IV. class water quality in terms of nitrogen, organic matter and heavy metals (Akın and Akın, 2007). In the study carried out in Gediz River, copper 0.034 ppm, chromium $0.099 \mathrm{ppm}$, nickel $0.062 \mathrm{ppm}$, lead $0.218 \mathrm{ppm}$, iron $0.121 \mathrm{ppm}$, manganese $0.053 \mathrm{ppm}$, zinc $1.181 \mathrm{ppm}$, cobalt $0.006 \mathrm{ppm}$, cadmium $0.0036 \mathrm{ppm}$ were found. The river was found dirty in terms of chrome and lead (Minareci et al., 2009a). In another study in Gediz River, boron concentrations are found between 0.19-2.25 mg $\mathrm{l}^{-1}$ (Demirbas and Orhun, 2008). The average boron value was $2.428 \mathrm{mg} \mathrm{l}^{-1}$ in Gediz River and Gediz River was determined as very polluted water for boron parameter (Minareci, 2014).

In Kucuk Menderes River, copper concentrations 0.01-0.02 ppm, chrome concentrations $0.01-0.02 \mathrm{ppm}$, nickel concentrations $0.03-0.08 \mathrm{ppm}$ and lead concentrations $0.08-0.12 \mathrm{ppm}$ were found between these amounts (Egemen et al., 2005). In the study conducted by Gundogdu and Ozkan (2006) in Kucuk Menderes River in 2006, it was determined that the iron value is $3^{\text {rd }}$ class water quality. In another study, it has been reported that the Kucuk Menderes River is in the $4^{\text {th }}$ class pollution level in terms of nitrogen, organic matter and heavy metals from domestic and industrial wastes and agricultural activities (Akın and Akın, 2007). It was determined that other heavy metal concentrations except $\mathrm{Ni}, \mathrm{Cu}$ and $\mathrm{Zn}$ were low in surface water of Kucuk Menderes River (Turgut, 2003).

Anionic detergent and heavy metal levels of Berdan Stream have been found higher than the standard levels (Kumbur and Vural, 1989).

The anionic detergent values are shown comparatively in Table 9. The obtained phosphate values from Buyuk Menderes River were lower than the obtained values from many other rivers (Table 10). 
Table 9. Anionic detergent concentrations of studies

\begin{tabular}{|c|c|c|}
\hline Rivers name & Detergent concentrations & References \\
\hline Gediz River & $0.023-4.48 \mathrm{mg} \mathrm{l}^{-1}$ & Tugrul, 1992 \\
\hline Yuvarlak Stream & $0.12 \mathrm{mg} \mathrm{l}^{-1}$ & Balık et al., 2002 \\
\hline Bakırcay River & $0.01-0.29 \mathrm{mg} \mathrm{l}^{-1}$ & Basaran, 2004 \\
\hline Kucuk Menderes River & $0-0.93 \mathrm{mg} \mathrm{l}^{-1}$ & Egemen et al., 2005 \\
\hline Gediz River & $0.951 \mathrm{mg}^{-1}$ & Minareci et al., 2009b \\
\hline Karacay Stream & $0.071-1.122 \mathrm{mg} \mathrm{l}^{-1}$ & Minareci et al., 2009b \\
\hline Halifax Harbour River & $0.001-\mathrm{mg} \mathrm{l}^{-1}$ & Gagnon, 1983 \\
\hline Tama River & $0.035-0.219 \mathrm{mg} \mathrm{l}^{-1}$ & Yoshikawa et al., 1984 \\
\hline Hyogo River & $0.004-2.5 \mathrm{mg} \mathrm{l}^{-1}$ & Kobuke, 1985 \\
\hline Tsurumi River & $0.01-0.29 \mathrm{mg} \mathrm{l}^{-1}$ & Yoshikawa et al., 1985 \\
\hline Sumida River & $0.005-0.01 \mathrm{mg} \mathrm{l}^{-1}$ & Kikuchi et al., 1986 \\
\hline Saar River & $0.01-0.09 \mathrm{mg} \mathrm{l}^{-1}$ & Matthijs and De Henau, 1987 \\
\hline Teshiro River & $0.01-0.27 \mathrm{mg} \mathrm{l}^{-1}$ & Kojima, 1989 \\
\hline Teganuma River & $0.019-1.4 \mathrm{mg} \mathrm{l}^{-1}$ & Nonaka et al., 1989 \\
\hline Yodo River & $0.043-0.089 \mathrm{mg} \mathrm{l}^{-1}$ & Nonaka et al., 1990 \\
\hline Miami River & $<0.05 \mathrm{mg} \mathrm{l}^{-1}$ & Hand et al., 1990 \\
\hline Oohori River & $0.5-1.6 \mathrm{mg} \mathrm{l}^{-1}$ & Amano et al., 1991 \\
\hline Mississippi River & $0.01-0.3 \mathrm{mg} \mathrm{l}^{-1}$ & McAvoy et al., 1993 \\
\hline Litheos River & $0.1 \mathrm{mg} \mathrm{l}^{-1}$ & Dassenakis et al., 1998 \\
\hline Yorkshire River & $0.05-0.25 \mathrm{mg} \mathrm{l}^{-1}$ & Fox et al., 2000 \\
\hline Itter River & $0.007-0.011 \mathrm{mg} \mathrm{l}^{-1}$ & Wind et al., 2004 \\
\hline Buyuk Menderes River & $0.0583-0.3385 \mathrm{mg} \mathrm{l}^{-1}\left(\right.$ mean $\left.0.2345 \mathrm{mg} \mathrm{l}^{\mathrm{l}^{-1}}\right)$ & This study \\
\hline
\end{tabular}

Table 10. Phosphate concentrations of studies

\begin{tabular}{|c|c|c|}
\hline Rivers name & Phosphate concentrations & References \\
\hline MericRiver & $0.0001-0.02 \mathrm{mg} \mathrm{l}^{-1}$ & Kontas, 1990 \\
\hline Gediz River & $0.016-4.054 \mathrm{mg} \mathrm{l}^{-1}$ & Tugrul, 1992 \\
\hline Gediz River & $0.02-7.41 \mathrm{mg} \mathrm{l}^{-1}$ & Okur et al., 1997 \\
\hline Asi River & $0.002-2.44 \mathrm{mg} \mathrm{l}^{-1}$ & Tasdemir and Goksu, 2001 \\
\hline Bakırcay River & $0.0018-0.0229 \mathrm{mg} \mathrm{l}^{-1}$ & Basaran, 2004 \\
\hline Bakırcay River & $0-0.7 \mathrm{mg} \mathrm{l}^{-1}$ & Gundogdu and Turhan, 2004 \\
\hline Karacay Stream & $0.22-6.82 \mathrm{mg} \mathrm{l}^{-1}$ & Kara and Comlekcioglu, 2004 \\
\hline Kucuk Menderes River & $0-1.88 \mathrm{mg} \mathrm{l}^{-1}$ & Egemen et al., 2005 \\
\hline Gediz River & $0.0044-0.2481 \mathrm{mg} \mathrm{l}^{-1}$ & Minareci et al., 2009b \\
\hline Karacay Stream & $0.002-0.225 \mathrm{mg} \mathrm{l}^{-1}$ & Minareci et al., 2009b \\
\hline Rheraya River & $0.043-1.286 \mathrm{mg} \mathrm{l}^{-1}$ & Khebiza et al., 2006 \\
\hline Nhue River & $3.5 \mathrm{mg} \mathrm{l}^{-1}$ & Duc et al., 2006 \\
\hline Dun River & $0.086 \mathrm{mg} \mathrm{l}^{-1}$ & Neal et al., 2006 \\
\hline Kenet River & $0.083 \mathrm{mg} \mathrm{l}^{-1}$ & Neal et al., 2006 \\
\hline Fuji River & $0.01-0.13 \mathrm{mg} \mathrm{l}^{-1}$ & Shrestha and Kazama, 2007 \\
\hline Yangtze River & $0.64-1.31 \mathrm{mg} \mathrm{l}^{-1}$ & Zhang et al., 2007 \\
\hline Buyuk Menderes River & $0.0087-0.0245 \mathrm{mg} \mathrm{l}^{-1}\left(\right.$ mean $\left.0.0181 \mathrm{mg} \mathrm{l}^{-1}\right)$ & This study \\
\hline
\end{tabular}




\section{Conclusions and recommendations}

The Buyuk Menderes River water is 2nd quality in terms of $\mathrm{pH}$, conductivity, anionic surfactant and nickel parameters. Also the river water is 3rd quality in terms of dissolved oxygen parameter. Because the Buyuk Menderes River is close to the settlements, the discharges reach to the river. Due to domestic and industrial waste load, pollution load increases.

For the sustainable productivity of the Buyuk Menderes Basin lands and the protection of all aboveground and underground waters from pollution,

- The protection of the Buyuk Menderes River from all kinds of pollution (especially domestic and industrial wastes),

- Analysis of surface and groundwater should be done periodically,

- The water not suitable for irrigation should not be used,

- Fertilizer should be used as much as necessary,

- The farmers are directed to organic farming,

- Use of pesticides should be minimized,

- Industrial facilities and local governments should establish and use wastewater treatment facilities,

- The chemical fertilizers and agrochemicals must be controlled by authorized institutions.

As a result, the investigation of the underground and surface water quality of Buyuk Menderes Basin should be continued periodically, the factors that decrease the quality should be revealed and necessary precautions should be taken.

Acknowledgements. This study is supported by Manisa Celal Bayar University Scientific Research Projects Coordination Unit within the frame of the projects numbers FEF 2012-099 and FEF 2013-139. We are indebted to MCBU-BAP fund for providing financial support to this study.

\section{REFERENCES}

[1] Akar, D. (2007): Potential boron pollution in surface water, crop and soil in the lower Buyuk Menderes basin. - Environmental Engineering Science 24: 1273-1279.

[2] Akcay, H., Oguz, A., Karapire, C. (2003): Study of heavy metal pollution and speciation in Buyuk Menderes and Gediz River sediment. - Water Research 37(4): 813-822.

[3] Akın, M., Akın, G. (2007): Suyun önemi, Türkiye'de su potansiyeli, su havzaları ve su kirliliği. - Ankara Universitesi Dil ve Tarih-Cografya Fakultesi Dergisi 47(2): 105-118.

[4] Amano, K., Fukushima, T., Nakasugi, O. (1991): Fate of linear alkyl benzene sulfonates in a lake estuary. - Water Science Technology 23: 497-506.

[5] Anonymous (1995): Standard methods for the examination of water and wastewater. 17th Edition. APHA, AWWA, WPCF, Washington.

[6] Anonymous (2005): Standard methods for the examination of water and wastewater. 21st Edition. APHA, AWWA, WEF, Washington.

[7] Aydin, G., Seferoglu, S. (2000): Investigation of boron concentration of some irrigation waters used in Aydin region for plant nutrient and soil pollution. - Proceedings of International Symposium on Desertification, 13-17 June 2000, Konya, Turkey, pp. 109115.

[8] Balık, S., Ustaoglu, M. R., Egemen, O., Cirik, S., Eltem, R., Sarı, H. M., Elbek, A. G., Guner, Y., Ozdemir, G., Ozdemir, M. D., Koksal, Y., Ozbek, M., Aygen, C., Tasdemir, 
A., Y1ldı, S., Ilhan, A., Topkara, E. T., Somek, H., Kaymakc1, A. (2002): The formulation of an action plan sustainable usage for Yuvarlak Stream. - T. C. Ministry of the Environment, Private Environmental Protection Establishment, Ankara, Turkey, pp. $182 \mathrm{p}$.

[9] Basaran, A. K. (2004): Pollution parameters in Bakırçay Delta and with relation Candarlı Bay. - PhD dissertation. The Institute of Natural Sciences, Ege University, Izmir, Turkey.

[10] Boyacioglu, H., Boyacioglu, H., Gunduz, O. (2004): Application of factor analysis in the assessment of surface water quality in Buyuk Menderes River Basin. - Proc. EWRA Symposium on Water Resources Management Risks and Challenges for the 21st Century 2.

[11] Bulut, C., Atay, R., Uysal, K., Kose, E. (2012): Civril Golu (Isıkl1 Golu) yüzey suyu kalitesinin degerlendirilmesi. - Anadolu Universitesi Bilim ve Teknoloji Dergisi - C Yaşam Bilimleri ve Biyoteknoloji 2(1): 1-8.

[12] Cakir, M., Minareci, O. (2015): Isıkl1 Golu ve Isıkl1 Cayı'nda (Civril-Denizli) deterjan, fosfat ve bor kirliliğinin araştırılması. - Istanbul Universitesi Su Urunleri Dergisi 30(1): 23-34.

[13] Dassenakis, M., Scoullos, M., Foufa, E., Krasakopoulou, E., Pavlidou, A., Kloukiniotou, M. (1998): Effects of multiple source pollution on a small Mediterranean river. - Applied Geochemistry 13: 197-211.

[14] Demirbas, P., Orhun, O. (2008): Kuzey Ege, Gediz ve Küçük Menderes Havzalarında 2003-2007 yılları arasında su kalitesi açısından bor içeriğinin spektrofotometrik analiz metodu ile belirlenmesi ve değerlendirilmesi. - 5. Dünya Su Forumu Bölgesel Hazırlık Sureci, Havza Kirliligi Konferans1, Izmir, Türkiye, pp. 47-56.

[15] Duc, T. A., Vachaud, G., Bonnet, M. P., Prieur, N., Loi, V. D., Anh, L. L. (2006): Experimental investigation and modeling approach of the impact of urban wastewater on a tropical river; a case study of the Nhue River, Hanoi, Vietnam. - Journal of Hydrology 334: 347-358.

[16] Durdu, O. F., Karatas, B. S., Tunalı, S. P. (2012): Buyuk Menderesi Kirletmek Geleceğini Kirletmektir. - Güney Ege Kalkınma Ajansı Proje Sonuç Raporu, Proje No: TR32/11/DFD-007-019. Adnan Menderes Universitesi Ziraat Fakultesi Tarımsal Yapılar ve Sulama Bölümü, Aydin, Türkiye.

[17] Egemen, O. (2011): Su Kalitesi. - 7. Bask1. Ege Universitesi Su Urunleri Fakultesi. Yayın No: 14, Bornova - Izmir, Türkiye.

[18] Egemen, O., Ustaoglu, M. R., Onen, M., Hakarerler, H., Sarı, H. M., Tanrıkul, T., Ozbek, M., Ilhan, A., Kaymakci Basaran, A. (2005): Water quality of Kucuk Menderes River and investigation of interaction with ecosystem. - Ege University Scientific Investigation Project Report.

[19] Fox, K., Holt, M., Daniel, M., Buckland, H., Guymer, I. (2000): Removal of linear alkyl benzene sulfonate from a small Yorkshire stream: contribution to GREAT-ER project 7. - The Science of the Total Environment 251/252: 265-275.

[20] Gagnon, M. J. (1983): Monitoring anionic surfactants at a sea outfall, Halifax Harbour, Canada. - Water Research 17: 1653-1659.

[21] Gundogdu, V., Ozkan, E. Y. (2006): Küçük Menderes Nehri Ölçüm Ağı Tasarımı ve Su Kalite Değişkenlerinin İrdelenmesi Çalışması. - Ege Universitesi Su Urunleri Dergisi 23(3-4): 361-39.

[22] Gundogdu, V., Turhan, D. (2004): Bakırcay Havzası kirlilik etüdü çalışması. - Dokuz Eylül Universitesi Muhendislik Fakultesi Fen ve Muhendislik Dergisi 6(3): 65-83.

[23] Hand, V. C., Rapaport, R. A., Pittinger, C. A. (1990): First validation of a model for the adsorption of linear alkyl benzene sulfonate (LAS) to sediment and comparison to hronic effects data. - Chemosphere 21: 741-750.

[24] Hatcher, J. T., Wilcox, L. V. (1950): Colorimetric determination of boron using. Analytical Chemistry 22(4): 567-569. 
[25] Kabay, N., Yilmaz, I., Bryjak, M., Yuksel, M. (2006): Removal of boron from aqueous solutions by ion exchange-membrane hybrid process. - Desalination 198: 74-81.

[26] Kara, C., Comlekcioglu, U. (2004): Karacay (Kahramanmaras)'in kirliliginin ve fiziko kimyasal parametrelerinin incelenmesi. - Kahramanmaras Sutcu Imam Universitesi Fen ve Muhendislik Dergisi 7(1): 1-7.

[27] Khebiza, M. Y., Boughrous, A. A., Gabbanini, C., Messouli, M., Messana, G. (2006): Impact of waste discharges on the water quality and interstitial community structure of two Mediterranean rivers. - Italian Journal of Zoology 73: 153-166.

[28] Kikuchi, M., Tokai, A., Yoshida, T. (1986): Determination of trace levels of linear alkyl benzene sulfonates in the marine environment by high-performance liquid chromatography. - Water Research 20: 643-650.

[29] Kobuke, Y. (1985): Concentration of linear alkyl benzene sulfonates (LAS) and its composition in the river waters of Hyogo Prefecture. - Japanese Journal of Limnology 46: 279-286.

[30] Kojima, S. (1989): Pollution by fluorescent whitening agents (FWA) and linear alkyl benzene sulfonates (LAS) in environmental water. - Announce Rep. Environment Pollution Research Inst. Nagoya 19: 61-68.

[31] Kontas, A. (1990): The pollution of Meric River and this pollution effects to Aegean Sea. Master thesis. -The Institute of Marine Sciences and Technology, Dokuz Eylül University, Izmir, Turkey.

[32] Kucuk, S. (2007): Buyuk Menderes Nehri su kalite olcumlerinin su urunleri acisından incelenmesi. - Adnan Menderes Universitesi Ziraat Fakultesi Dergisi 4: 7-13.

[33] Kumbur, H., Vural, N. (1989): Investigation of Metal and Detergent Pollution of Berdan Stream. - Journal of the Faculty of Engineering and Architecture of Gazi University 4(12): 25-41.

[34] Matthijs, E., De Henau, H. (1987): Determination of LAS. - Tenside Surfactants Detergents 24: 193-199.

[35] McAvoy, D. C., Eckhoff, W. S., Rapaport, R. A. (1993): Fate of linear alkyl benzene sulfonate in the environment. - Environmental Toxicology and Chemistry 12: 977-987.

[36] Minareci, O. (2014): Investigation of Boron Pollution in the Gediz River. - Ekoloji 23(91): 91-97.

[37] Minareci, O., Cakir, M. (2018): Determination of Detergent, Phosphate, Boron and Heavy Metal Pollution in Adiguzel Dam Lake (Denizli/Turkey). - Journal of the Institute of Science and Technology 8(1): 61-67.

[38] Minareci, O., Ozturk, M., Minareci, E. (2009a): Determination of some heavy metal concentrations in water and sediment sample staken from Gediz River (Turkey). Fresenius Environmental Bulletin 18(3): 270-274.

[39] Minareci, O., Ozturk, M., Egemen, O., Minareci, E. (2009b): Detergent and Phosphate Pollution in Gediz River, Turkey. - African Journal of Biotechnology 8(15): 3568-3575.

[40] Neal, C., House, W. A., Jarvie, H. P., Neal, M., Hill, L., Wickham, H. (2006): The water quality of the River Dun and the Kenet and Avon Canal. - Journal of Hydrology 330: $155-170$.

[41] Nonaka, K., Hattori, Y., Nakamoto, M. (1989): Determination of LAS in environmental and domestic wastewaters. - Suishitsu Odaku Kenkyo 12: 194-200.

[42] Nonaka, K., Hayashi, Y., Nakamoto, M. (1990): The distribution and fate of LAS in some river waters of Osaka. - Announce Rep. Environment Pollution Control Cent. Osaka Prefect. Gov. 12: 68-79.

[43] Official Gazette (1991): Water Pollution Control Regulation Technical Procedures Bulletin. - No: 20748.

[44] Official Gazette (2004): Water Pollution Control Regulation. - No: 25687.

[45] Official Gazette (2012): Above ground Water Quality Regulation. - No: 28483.

[46] Okur, B., Hakerlerler, H., Anac, D., Anac, S., Dorsan, F., Yagmur, B. (1997): An investigation on monthly and seasonal variation of some pollution parameters of Gediz 
River. - Ege University Investigation Fund, Project Number: 93-ZRF-043, Izmir, Turkey, pp. 1-47.

[47] Parsons, T. R., Matia, Y., Lalli, C. M. (1984): A manual of chemical and biological methods for seawater analysis. - Pergamon Pres., New York.

[48] Samsunlu, A. (1999): Çevre Muhendisligi Kimyası. - Sam-Cevre Teknolojileri Merkezi Yayın1, Istanbul.

[49] Shrestha, S., Kazama, F. (2007): Assessment of surface water quality using multivariate statistical techniques: A case study of the Fuji river basin, Japan. - Environmental Modeling and Software 22: 464-475.

[50] Tasdemir, M., Goksu, L. Z. (2001): Asi Nehri'nin (Hatay, Türkiye) bazı su kalite özellikleri. - Ege Universitesi Su Urunleri Dergisi 18(1-2): 55-64.

[51] Tubitak Mam (2013): Basin Conservation Action Plans - Buyuk Menderes Basin. Tubitak Marmara Research Center Environment Institute.

[52] Tugrul, G. (1992): Investigation of anionic detergent pollution in Gediz River system. Master thesis. - Ege University Biology Department, Izmir, Turkey.

[53] Turgut, C. (2003): The contamination with organochlorine pesticides and heavy metals in surface water in Kucuk Menderes River in Turkey, 2000-2002. - Environment International 29: 29-32.

[54] Wind, T., Werner, U., Jacob, M., Hauk, A. (2004): Environmental concentrations of boron, LAS, EDTA, NTA and Triclosan simulated with GREAT-ER in the river Itter. Chemosphere 54: 1135-1144.

[55] Yoshikawa, S., Sano, H., Harada, T. (1984): Determination of LAS in river water by high-performance liquid chromatography. - Suishitsu Odaku Kenkyu 7: 191-194.

[56] Yoshikawa, S., Sano, H., Harada, T. (1985): Distribution of LAS in river water and sediment at Tsurumi River. - Japanese Journal of Water Pollution Research 8: 755-758.

[57] Zhang, Q., Shi, X., Huang, B., Yu, D., Öborn, I., Blomback, K., Wang, H., Pagella, T. F., Sinclair, F. L. (2007): Surface water quality of factory - based and vegetable- based periurban areas in the Yangtze River Delta region, China. - Catena 69: 57-64. 